\title{
Trombofilia no Brasil
}

\author{
Godoy JMP. ${ }^{1}$ \\ ${ }^{1}$ Belo Horizonte - Brasil. \\ E-mail: godoyjmp@gmail.com
}

Godoy, J.M.P. 2013. Trombofilia no Brasil, p.76. In: Bastos, Francisco Reis. Anais do V Simpósio Internacional de Flebologia [Blucher Medical Proceedings n.1 v.1]. São Paulo: Blucher, 2014 http://dx.doi.org/10.5151/medpro-flebo-SIF_49

\section{Introdução}

As trombofilias estão associadas a eventos tromboembólicos venoso-arteriais podendo acarretar morbidade e mortalidade. A interferência da cor, raça e outros fatores podem levar a diferente prevalência, portanto dados regionais se tornam importantes na abordagem desses pacientes.

\section{Método}

Revisão de literatura de trabalhos brasileiros abordando as principais trombofilias (fator $\vee$ de Leiden, mutação G 20210-A no gene da protrombina, deficiência das proteínas C e S e da hiper-homocientínemia) e as principais causas de hipercoagulabilidade adquiridas envolvidas com a prática clínica.

\section{Resultado}

As maiores prevalências detectadas de trombofilias congênitas são do fator $V$ de Leiden e da hiper-homocisteina e de hipercoagulabilidade adquirida os anticorpos anticardiolipina e síndrome para neoplásica.

\section{Conclusão}

A alta prevalência da hiper-homocisteínemia e da síndrome da paraneoplásicas nas faixas etárias entre os 50 a 80 anos alertam para essas ocorrências.

Palavras chave: Trombofilia, prevalência, revisão literatura. 